\title{
Histological Evaluation of the Effects of Borax Obtained from Various Sources in Different Rat Organs
}

\author{
Evaluación Histológica de los Efectos del Borax Obtenido \\ de Diversas Fuentes en Diferentes Órganos de Rata
}

\author{
Mustafa Kabu*; Murat Tosun**; Bülent Elitok ${ }^{* * * *}$ \& Murat Sırrı Akosman ${ }^{* * * * * *}$
}

KABU, M.; TOSUN, M.; ELITOK, B. \& AKOSMAN, M. S. Histological evaluation of the effects of borax obtained from different sources in different rat organs. Int. J. Morphol., 33(1):255-261, 2015.

SUMMARY: Boron is an essential element for life and intake via different sources into the body. Because effects of boron and compounds on the body has not been studied enough especially in tissue level, we planned this study to evaluate the effects of borax the most intaken form of boron compound on different intraabdominal organs histologically and also clinically. 42 male rats divided into equal 7 groups and different toxicological doses consistent with its LD50 dose $(5000 \mathrm{mg} / \mathrm{kg} / \mathrm{d})$ were administered by gavage except control and sham groups. In the study, 2 different kinds of borax one of which was produced for research and the other for agriculture but the same formulation, were used and their effects were also compared. As a result it was found that borax did not cause any histological changes in kidney, large intestine, liver and stomach in lower doses. But if doses were increased, a slightly inflammatory cell migration was detected without clinical signs in liver and large intestine. However, when a single very high dose of borax was administered, very high edema, inflammatory cell migration and neovascularization was observed and clinically 2 out of 6 rats died within 5 hours. We suggested that very high dose intake of borax may cause sudden death and also during long periods and higher dose intake may pave the way of inflammatory bowel diseases. At the same time, in boron related studies we advice that the kind of boron and also their source should be evaluated carefully and the most suitable compound should be chosen in case of faulty results.

KEY WORDS: Boron; Borax; Inflammatory bowel disease; Histopathology; Toxicology.

\section{INTRODUCTION}

Boron is a chemical element with atomic number 5 and symbol $\mathrm{B}$ in periodic table and essential for life. The most common sources of the boron on earth' crust are Turkey, United States, Argentina, Chile, Russia, China and Peru (Chong et al., 2000). Boron generally exists in rocks, coal, soil and seawater (Samman et al., 1998) and is released into the atmosphere by forest fires, coal combustion, volcanoes and commercial uses (Howe, 1998). It is commercially used for the manufacture of glass, detergent, ceramic and fertilizer (Argust, 1998). Dehydrated borax and borax pentahydrate are used for fertilizers in plants, surface waters and ground waters (Goldbach, 1997; Hasenmueller \& Criss, 2013; Lovatt \& Dugger, 1984). Although boron has a very low toxic effect on mammals, it is very toxic to arthropods and used for insecticides. On the other hand, boric acid another form of boron, is used as an antibiotic in some superficial infections in humans (Irschik et al., 1995).
Boron is an essential element for dietary intake for human and animals (Hunt et al., 1994; Nielsen, 1997) and it should be consumed daily with foods and beverages (Sabuncuoblu et al., 2006). Furthermore, fruits and vegetables are the primary sources of boron (Hunt et al., 1991), plants have higher boron levels ( 0.1 to $0.6 \mathrm{mg}$ boron/ $100 \mathrm{~g}$ ) than foods of animal origin (0.01 to $0.06 \mathrm{mg} / 100 \mathrm{~g}$ ) (Newnham, 1997; Naghii, 1999). In vegetables, boron is especially found at the highest levels in leafy greens (Newnham).

The most daily consumed types of boron in mammalian life are Sodium tetraborate decahydrate (STD) and pentahydrate (STP) which are intakes via food and drinking water and excretes via urinary system. However, because preparation of the elemental boron is extremely difficult, the detailed boron mechanism on mammalians

* Department of Internal Medicine, Faculty of Veterinary Medicine, University of Afyon Kocatepe, Afyonkarahisar, Turkey.

** Department of Histology and Embryology, Faculty of Medicine, University of Afyon Kocatepe, Afyonkarahisar, Turkey.

**** Department of Internal Medicine, Faculty of Veterinary Medicine, University of Afyon Kocatepe, Afyonkarahisar, Turkey.

***** Department of Anatomy, Faculty of Veterinary Medicine, University of Afyon Kocatepe, Afyonkarahisar, Turkey. 
and also probable side effects have not yet been sufficiently described. Instead, different compounds of boron has been used for different studies. Thus, because the most daily consumed form is STD for mammalians, in this study, we aimed to investigate histopathological effects of STD on different intraabdominal organs such as intestine, stomach, liver and kidney in rats. However, because STD is produced both commercially for research by international companies and for fertilizer by national companies, for example in Turkey (Eti Mine Industrial Company) which is the main boron provider for agricultural fertilizer, we also aimed to compare histopathological effects of these products on the organs described above. Although different studies has been carried out for the effects of boron on mammalians, this is the first study evaluating histopathological effects on different organs in literature.

\section{MATERIAL AND METHOD}

Animals. The protocols of this experimental study were approved by the Animal Ethics Committee of Afyon Kocatepe University. All animals received human care in compliance with the "Principles of Laboratory Animal Care" formulated by the National Society for Medical Research and the "Guide for the Care and the Use of Laboratory Animals" prepared by the National Academy of Science and published by the National Institutes of Health (NIH publication Nr. 85e23, revised in 1985).

The 42 male Sprague-Dawley rats weighing 250$300 \mathrm{gm}$ were purchased and maintained in the Animal Research Center at Afyon Kocatepe University in Afyonkarahisar, Turkey during $21 \mathrm{~d}$. All rats were placed in steel mesh 19"x12"x12" cages and exposed to $12 \mathrm{~h}$ light/ 12 hours dark photoperiod with $20-24{ }^{\circ} \mathrm{C}$ room temperature. The rats were fed with a standard rat diet (100 $\mathrm{g} / \mathrm{d}$ ) and tap water.

Groups, dosages and treatments. The rats were divided into seven equal groups $(n=6)$ considering the STD intake and excretion dose from the body. Two kinds of STD used for study. One of these was purchased from Eti Mine Industrial Company General Management Kırka/Turkey (Na2B407.10H2O) (STD-E) which is generally used for fertilizer in agriculture and the other was purchased from Sigma-Aldrich Chemical Co. (St Louis, Missouri, USA) (Na2B407.10 H2O) (STD-S) which is used for research. There was no difference between these compounds except excipial products in STD-S. Boraxes were dissolved in tap water and administered daily by gavage except for the control group (Group I). The sham group (Group II) received $1 \mathrm{ml} /$ day tap water by gavage for $21 \mathrm{~d}$. On the other hand, LD50/5 (1 g/kg/d) STD-E were given to Group III and and also same dose STD-S were given to Group IV by gavage during 21 days. At the same time LD50 (5 g/kg/d) STD-E were given to Group V and and also same doses of STD-S were given to Group VI by gavage during 21 days. At last in Group VII only single doses of LD50x2 (10 g/ $\mathrm{kg} / \mathrm{d})$ STD-S were given by gavage at the end of study for evaluating acute dose effects of STD-S. All the groups were summarized in Table I.

Histology. All animals were sacrificed at the end of the experiment. The stomach, large intestines, liver and kidneys were excised, sampled and fixed in $10 \%$ neutral buffered formalin. All tissues were then processed histologically and embedded into paraffin. The paraffin blocks were sectioned into slices $5 \mu \mathrm{m}$ in thickness, mounted onto slides and stained with hematoxylene and eosine. In the histological evaluation, general properties of the tissues, oedema, neovascularization and migration of inflammatory cells were evaluated semiquantitatively in the slides under a light microscope (Table II).

\section{RESULTS}

Clinical results. At the end of the single dose trial in Group VII, 2 out of 6 rats died in 5 hours following symptoms of dyspnea, cyanosis, tremor and impairment in general condition. The other rats in this group showed signs of

Table I. The groups' specifications.

\begin{tabular}{lccc}
\hline & STD-E dose by gavage & S TD-S dose by gavage & Water by gavage \\
\hline Group I $(\mathrm{n}=6)$ & --- & -- & --- \\
Group II $(\mathrm{n}=6)$ & -- & -- & $1 \mathrm{ml} / \mathrm{d} 21 \mathrm{days}$ \\
Group III $(\mathrm{n}=6)$ & $\mathrm{LD} 50 / 5(1 \mathrm{mg} / \mathrm{kg} / \mathrm{d}) 21$ days & LD50/5 $(1 \mathrm{mg} / \mathrm{kg} / \mathrm{d}) 21 \mathrm{days}$ & --- \\
Group IV $(\mathrm{n}=6)$ & -- & - & --- \\
Group V $(\mathrm{n}=6)$ & LD50 $(5 \mathrm{mg} / \mathrm{kg} / \mathrm{d}) 21$ days & LD50 $(5 \mathrm{mg} / \mathrm{kg} / \mathrm{d}) 21 \mathrm{days}$ & --- \\
Group VI $(\mathrm{n}=6)$ & --- & LD50x2 Single dose $(10 \mathrm{mg} / \mathrm{kg} / \mathrm{d})$ & --- \\
Group VII $(\mathrm{n}=6)$ & --- & & \\
\hline
\end{tabular}


Table II. Semiquantitative analysis of all groups.

\begin{tabular}{|c|c|c|c|c|c|c|c|}
\hline & Oedema & & $\begin{array}{l}\text { Inflammat } \\
\text { cell migrat }\end{array}$ & & Neovasculari & & Total Score \\
\hline Group I & Kidney & 0 & Kidney & 0 & Kidney & 0 & 0 \\
\hline$(n-6)$ & Large Intestine & 0 & Large Intestine & 0 & Large Intestine & 0 & 0 \\
\hline & Stomach & 0 & Stomach & 0 & Stomach & 0 & 0 \\
\hline & Liver & 0 & Liver & 0 & Liver & 0 & 0 \\
\hline Group II & Kidney & 0 & Kidney & 0 & Kidney & 0 & 0 \\
\hline$(\mathrm{n}=6)$ & Large Intestine & 0 & Large Intestine & 0 & Large Intestine & 0 & 0 \\
\hline$(n=0)$ & Stomach & 0 & Stomach & 0 & Stomach & 0 & 0 \\
\hline & Liver & 0 & Liver & 0 & Liver & 0 & 0 \\
\hline Group III & Kidney & 0 & Kidney & 0 & Kidney & 0 & 0 \\
\hline$(n=6)$ & Large Intestine & 0 & Large Intestine & 0 & Large Intestine & 0 & 0 \\
\hline & Stomach & 0 & Stomach & 0 & Stomach & 0 & 0 \\
\hline & Liver & 0 & Liver & 0 & Liver & 0 & 0 \\
\hline Group IV & Kidney & 0 & Kidney & 0 & Kidney & 0 & 0 \\
\hline$(n=6)$ & Large Intestine & 0 & Large Intestine & 0 & Large Intestine & 0 & 0 \\
\hline$(n=0)$ & Stomach & 0 & Stomach & 0 & Stomach & 0 & 0 \\
\hline & Liver & 0 & Liver & 0 & Liver & 0 & 0 \\
\hline Group V & Kidney & 0 & Kidney & 0 & Kidney & 0 & 0 \\
\hline$(n=6)$ & Large Intestine & 0 & Large Intestine & 1 & Large Intestine & 0 & 1 \\
\hline & Stomach & 0 & Stomach & 0 & Stomach & 0 & 0 \\
\hline & Liver & 0 & Liver & 0 & Liver & 0 & 0 \\
\hline Group VI & Kidney & 0 & Kidney & 0 & Kidney & 0 & 0 \\
\hline$(n=6)$ & Large Intestine & 1 & Large Intestine & 2 & Large Intestine & 1 & 4 \\
\hline$(n=0)$ & Stomach & 0 & Stomach & 0 & Stomach & 0 & 0 \\
\hline & Liver & 0 & Liver & 1 & Liver & 0 & 1 \\
\hline Group VII & Kidney & 0 & Kidney & 0 & Kidney & 0 & 0 \\
\hline$(n-6)$ & Large Intestine & 2 & Large Intestine & 4 & Large Intestine & 2 & 8 \\
\hline$(n=6)$ & Stomach & 0 & Stomach & 0 & Stomach & 0 & 0 \\
\hline & Liver & 2 & Liver & 3 & Liver & 0 & 5 \\
\hline
\end{tabular}

$0=$ No positivity, $1=$ Slight positivity, $2=$ Mild positivity, $3=$ High positivity, $4=$ Very high positivity.

stress such as anxiety, nutrional impairment and nestle up. However, approximately one day later all signs disappeared and the rats normalized completely. There were no clinical signs and symptoms in the other groups during 21 days.

Histological results. Although there were no histological differences between Group II to Group VII when compared with Group I (Control) in stomachs and kidneys (Figs. 1, 2 and 3), the small numbers of inflammatory cell clusters were observed in the lamina propria of large intestines in Group VI (Fig. 4) and also large amounts of inflammatory cell clusters appear as bigger than diffuse lymph nodes and mild oedema were observed in both lamina propria and tunica submucosa of large intestine in Group VII (Fig. 4).

Additionally, an increased number of stellate macrophages was observed in the livers of Group VI and Group VII rats and no histological changes such as asinus impairments, dysmorphology of the hepatocytes, or sinusoidal dilation were detected in this and the other groups (Fig. 4).

In Groups II, III, IV and V, there were no histopathological alterations in the investigated organs.

\section{DISCUSSION}

The effects of boron on human body has been the subject of many previous studies. Although it was suggested that boron has no mutagenic or carcinogenic effects in some studies (Basaran et al., 2012; Zafar \& Ali, 2013), in other studies, it was shown that boron can have harmful effects on different organs such as urogenital system and gastrointestinal system (Bustos-Obregon et al., 2008; Ku \& Chapin, 1994). On the other hand, in a study it was shown 


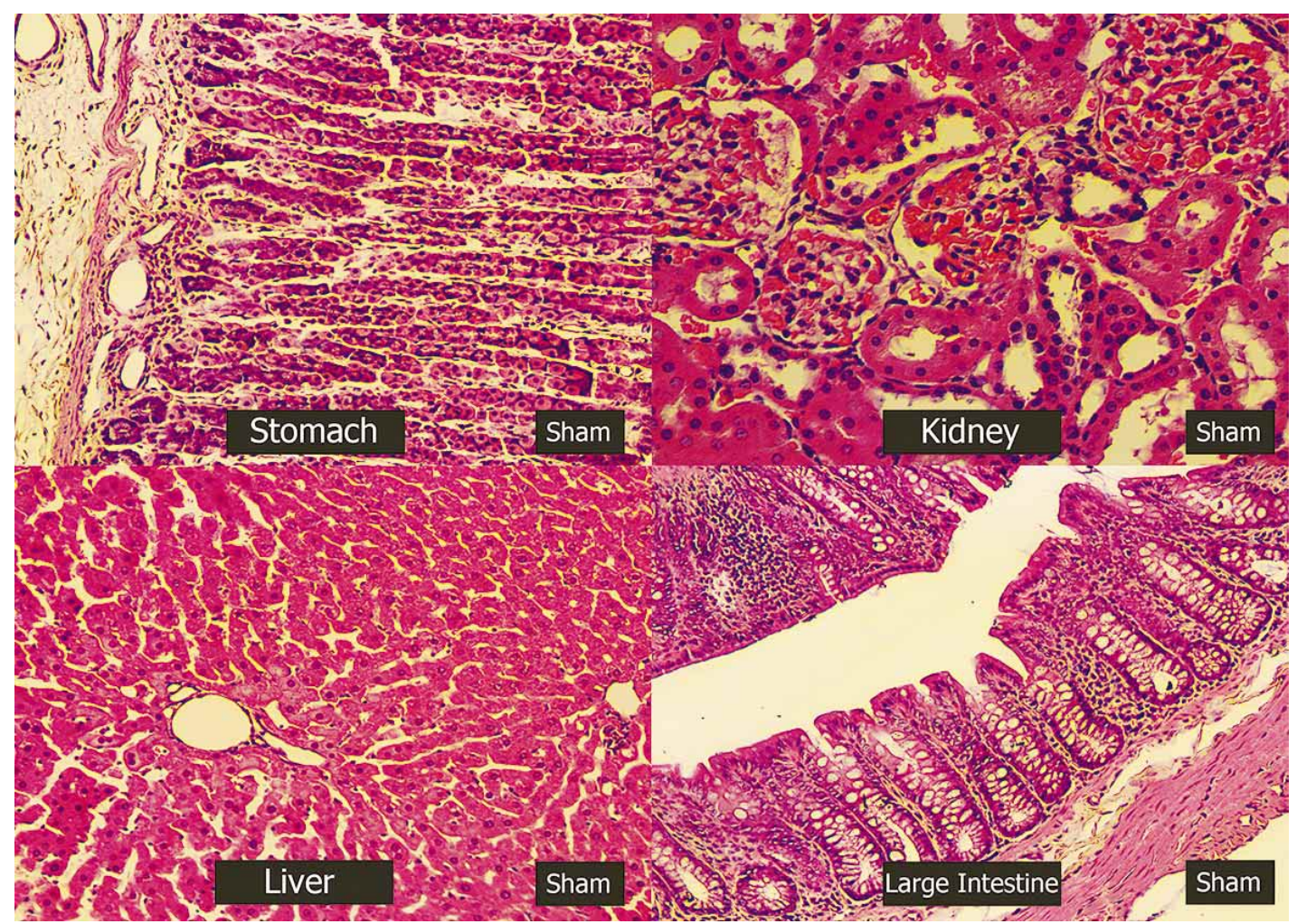

Fig. 1. The histological features of the organs we studied in Group II (Sham). There are no pathological changes in all tisues. Hematoxylene-Eosin.

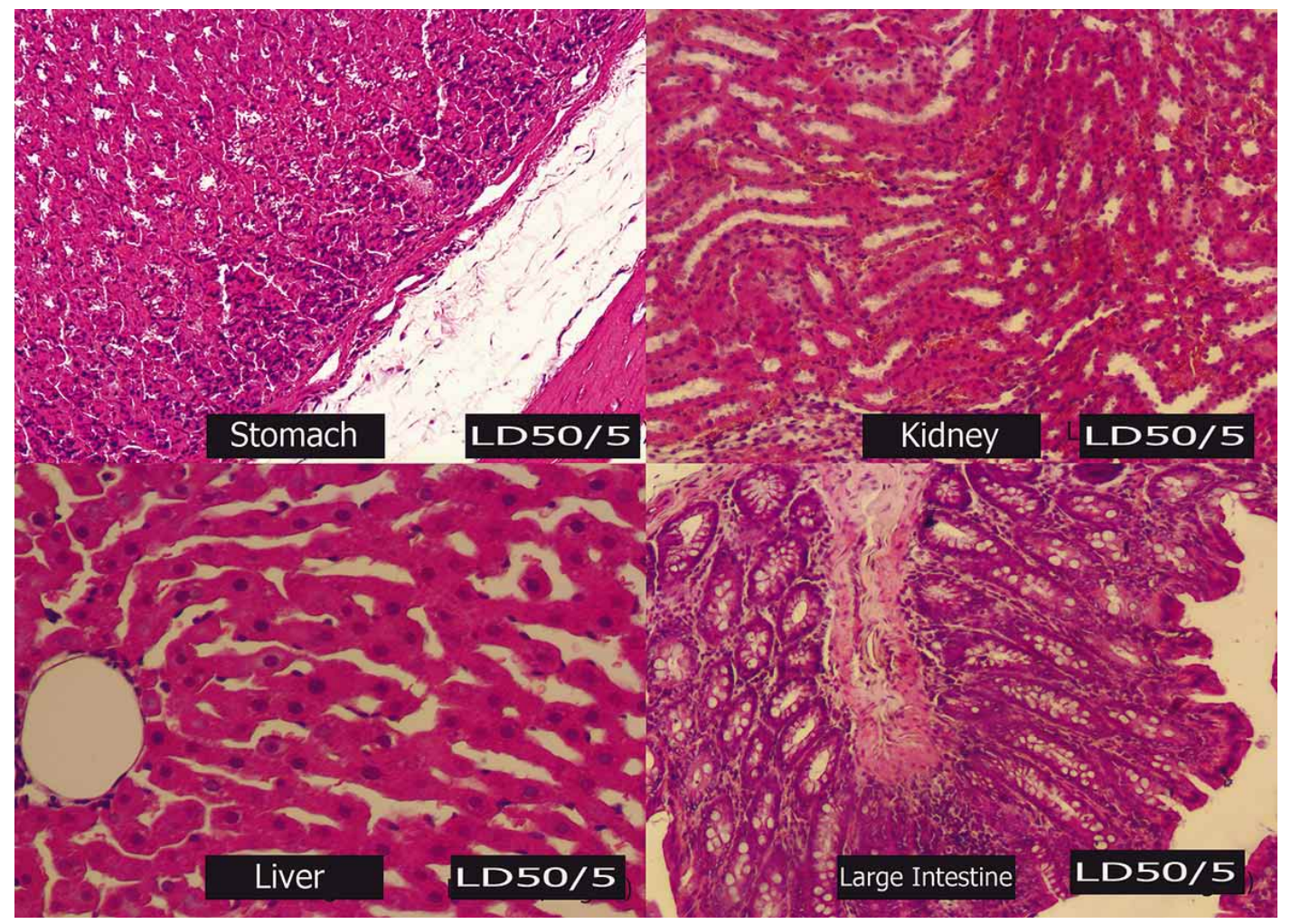

Fig. 2. The histological features of the organs we studied in LD50/5 dose administered rats. There are no pathological changes in all tisues. Hematoxylene-Eosin. 


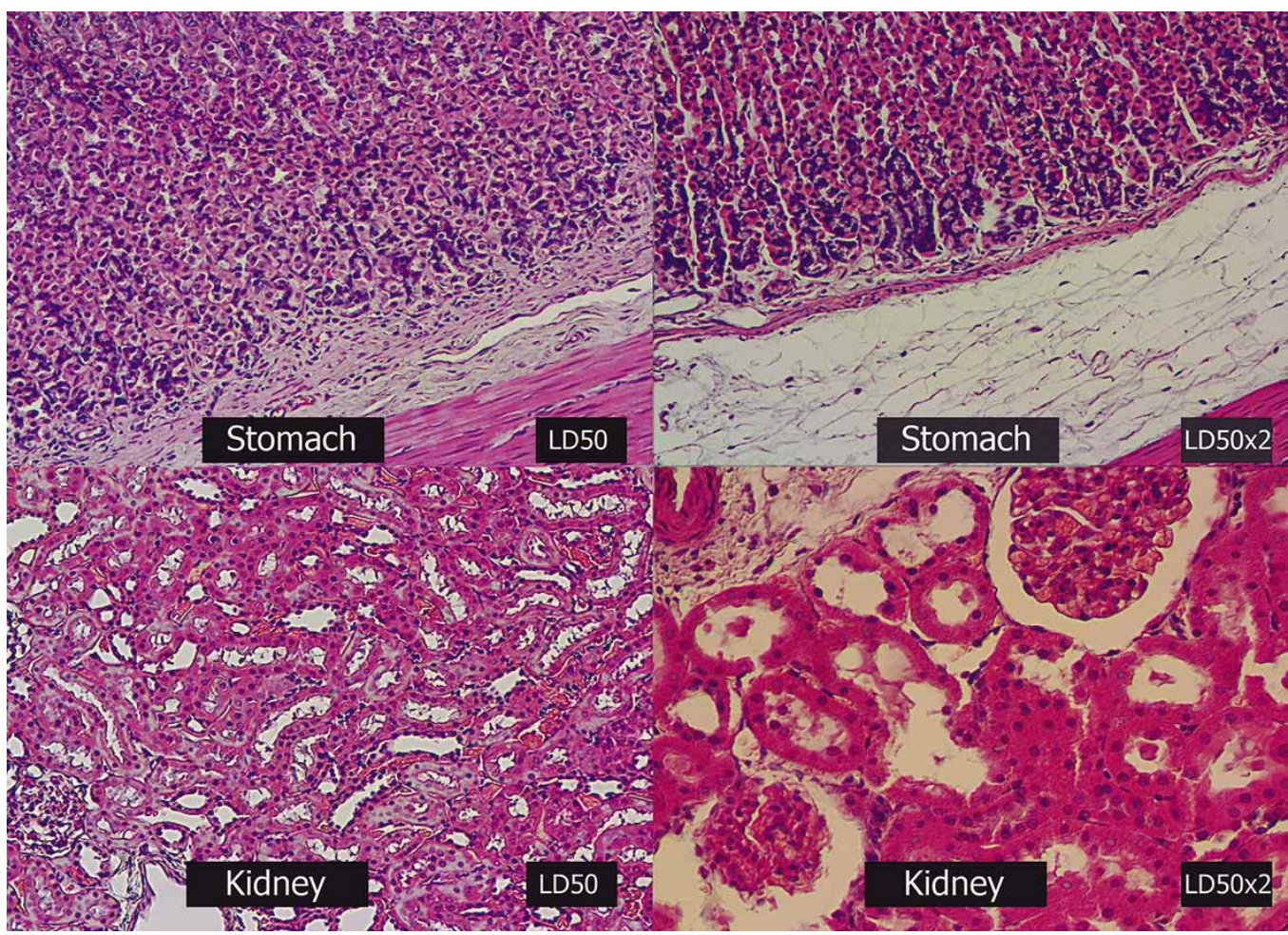

Fig. 3. The histological features of the stomach and kidney in LD50 and LD50x2 dose administered rats. There are no pathological changes in all tisues. Hematoxylene-Eosin.

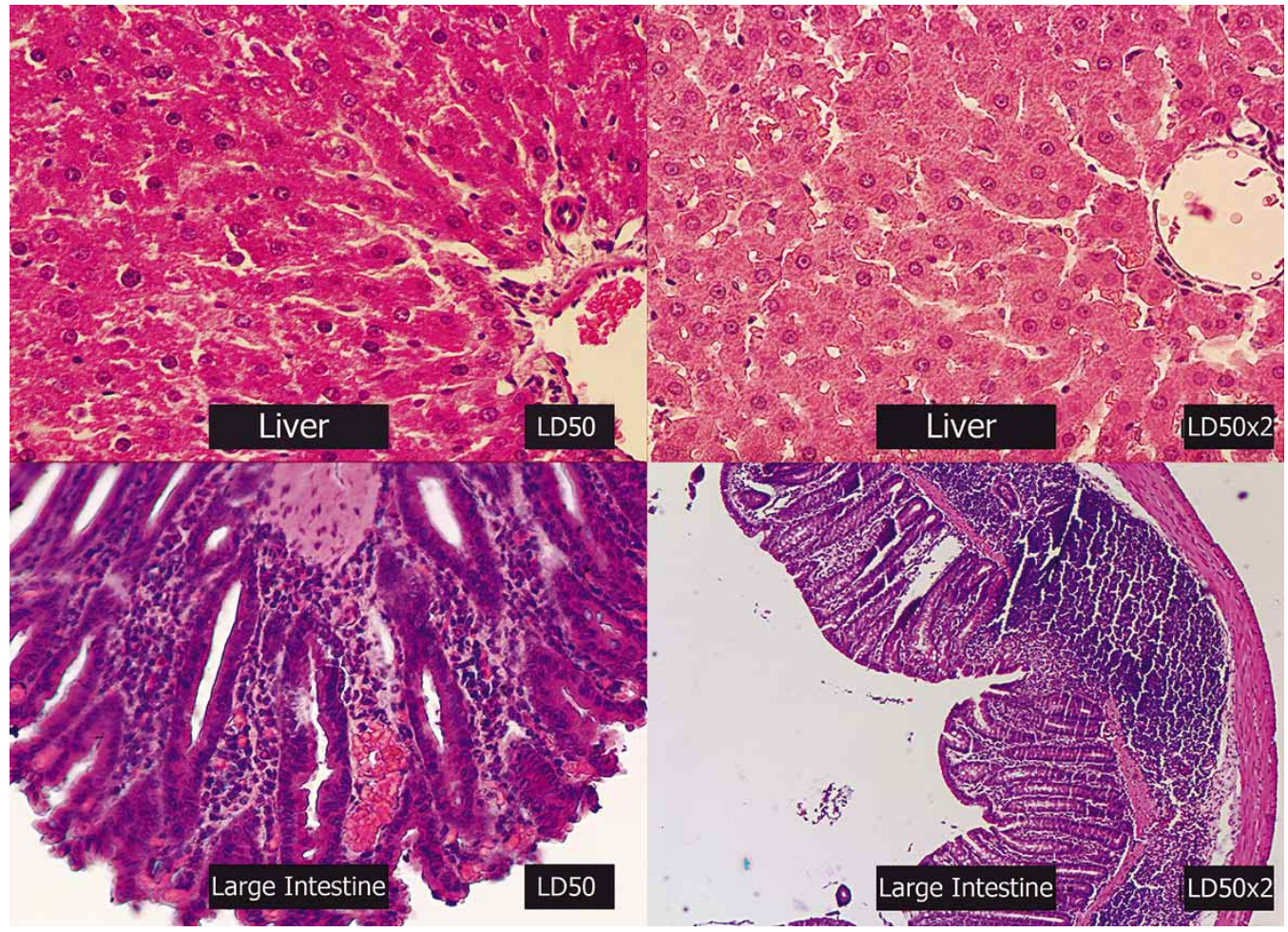

Fig. 4. The histological features of the liver and large intestine in LD50 and LD50x2 dose administered rats. Note that the mild inflammatory cell migration in LD50 dose administered rats' large intestine and massive migration in LD50x2 dose administered large intestine. At the same time, also note that the clear increase of Kuppfer cell in LD50x2 dose administered liver. Hematoxylene-Eosin. 
that boron had no reprotoxic effects on humans even at higher blood levels (Basaran et al.) In fact, existing research investigating the toxicological effects of boron and compounds on internal organs is inadequate. In a study about the histopathological effects of boron on mice liver at a dose of $12 \mathrm{mg} / \mathrm{l}$ in drinking water, it was detected that this level caused a significant increase in the numbers of binucleated cells in the adult mice and impaired collagenolysis in the livers of both juvenile and adult mice (Bustos-Obregon et $a l$.) However, contrary to this study, in another study it was proposed that boron can be beneficial in the treatment of hepatocellular carcinoma. In this study, in thiocetamideinduced hepatocellular carcinoma model, it was shown that boron has beneficial effects on proliferating cell nuclear antigen index and ameliorate oxidative stress (Zafar \& Ali). Moreover, in yet another study it was suggested that borax positively affected on the $\mathrm{Ca}$ and $\mathrm{Mg}$ metabolism in pregnant dairy cattle (Kabu et al., 2013).

The present study has pointed out that regular STD intake had no harmful effects on some gastrointestinal system organs such as stomach, large intestine and liver and also kidneys at lower doses. In a long term study, it was shown that LD50 dose administration caused weight loss and anxiety (Weir \& Fisher, 1972). However, in our study, the same dose did not show any signs and symptoms in any group, except Group VII. But in Group VII which was single administered dose of LD50x2 STD-S, it was detected that 2 out of 6 rats died from respiratory stress such as dyspnea and cyanosis, tremor and impairment of general condition. However, these clinical signs are similar to the same study described above. In that study the signs characterized with depression, ataxia, convulsions and death had been detected in LD50 dose administered rats (Weir \& Fisher). However, there were few studies in literature about long time effects of boron and compounds clinically in different doses. At the same time, originally, our study is the first study in which different doses of STD (s) were compared both clinical and histological levels.

In histological evaluation we detected that although there were no effects on stomachs and kidneys histology in all groups compared to Group I (Control), interestingly, there was serious, dose dependent, inflammatory cells migration and edema detected in Group VII. On the other hand in Group VI it was evaluated that inflammatory cell migration was very clear in lamina propria. At the same time, the number of stellate macrophages and inflammatory cells equal to macrophage in liver were increased significantly in Group VII.

In this study, we found that purified and different excipials administered borax (STD-S) and routinely used but has same formulation with STD-S borax form (STD-E) has almost the same clinical and histological effects on stomach, intestines, liver and kidneys in lower doses. However, if the doses were increased very much, STD-S can be very toxic even lethal in acute dose intake which may be related with excipials in this formulation. However, as in shown our study, these acute side effects were transient, if the organism reacted strongly enough. On the other hand, although there were no clinical and histological findings in STD-E administered group rats, increasing the inflammatory cells migration in large intestines is the most important result for us. Because increasing inflammatory cell migration can cause different inflammatory bowel syndromes such as Crohn disease and colitis ulcerosa. So we can say that high and/or long term borax intake can pave the way for these or related disorders

In this study, we suggest that routinely produced and used borax has no side effects on some of the vital organs we studied, which are stomach, intestine, kidney and liver. However, purified and produced for research borax has some important dose dependent side effects especially on large intestines and also lethal effects in very high dose acute intake. So we advice that when a study designed for evaluating boron and compounds effects, origin of chemical and its formulation, contents should be controlled carefully in case of faulty data obtained. On the other hand, new studies should be designed for evaluating possible risk of borax on inflammatory bowel diseases in large mammalian groups.

KABU, M.; TOSUN, M.; ELITOK, B. \& AKOSMAN, M. S. Evaluación histológica de los efectos del boro obtenido de diversas fuentes en diferentes órganos de rata. Int. J. Morphol., 33(1):255-261, 2015.

RESUMEN: El boro es un elemento esencial para la vida e ingresa a través de diferentes fuentes al cuerpo. Dado que los efectos del boro y sus compuestos en el cuerpo no se han estudiado lo suficiente, especialmente a nivel tisular, se planificó este estudio para evaluar sus efectos y la forma de consumo más común del compuesto de boro sobre diferentes órganos intraabdominales a nivel histológico y clínico. Cuarenta y dos ratas macho divididas en 7 grupos, con diferentes dosis toxicológicas de acuerdo con su dosis DL50 (5000 mg/kg/d) administradas por sonda, excepto en los grupos control y simulado. En el estudio fueron usados 2 tipos diferentes de boro, uno producido para la investigación y el otro para la agricultura, pero de la misma formulación, y sus efectos fueron comparados. Se encontró que el boro no causó cambios histológicos en el riñón, intestino grueso, hígado y estómago en dosis bajas. Sin embargo, al aumentar la dosis, se detectó una leve migración de células inflamatorias, sin signos clínicos, en el hígado e intestino grueso. Por otra parte, cuando se administró una sola dosis muy alta de boro, se observó un amplio edema, migración de células inflamatorias y neovascularización; clínicamente 2 de 6 ratas murieron dentro de 5 horas. Sugerimos que la ingesta de do- 
sis muy altas de bórax pueden causar la muerte súbita, además la ingesta de dosis altas y durante periodos de tiempo prolongado puede causar enfermedades inflamatorias del intestino. Es recomendable que en los estudios relacionados con el boro, el tipo de boro así como su fuente sean evaluados cuidadosamente, eligiendo el compuesto más adecuado en caso de resultados erróneos.

PALABRAS CLAVE: Boro; Bórax; Enfermedad inflamatoria intestinal; Histopatología; Toxicología.

\section{REFERENCES}

Argust, P. Distribution of boron in the environment. Biol. Trace Elem. Res., 66(1-3):131-43, 1998.

Basaran, N.; Duydu, Y. \& Bolt, H. M. Reproductive toxicity in boron exposed workers in Bandirma, Turkey. J. Trace Elem. Med. Biol., 26(2-3):165-7, 2012.

Bustos-Obregon, E.; Hartley Belmar, R. \& Catriao-Gálvez, R. Histopathological effects of boron on mouse liver. Int. J. Morphol., 26(1):155-64, 2008.

Chong, G.; Pueyo, J. \& Demergasso, C. Los yacimientos de boratos de Chile. Rev. Geol. Chile, 27(1):99-119, 2000.

Samman, S.; Naghii, M. R.; Lyons Wall, P. M. \& Verus, A. P. The nutritional and metabolic effects of boron in humans and animals. Biol. Trace Elem. Res., 66(1-3):227-35, 1998.

Goldbach, H. E. A critical review on current hypotheses concerning the role of boron in higher plants: suggestions for further research and methodological requirements. J. Trace Micr. Technol., 15:51-91, 1997.

Hasenmueller, E. A. \& Criss, R. E. Multiple sources of boron in urban surface waters and groundwaters. Sci. Total Environ., 447:235-47, 2013.

Howe, P. D. A review of boron effects in the environment. Biol. Trace Elem. Res., 66(1-3):153-66, 1998.

Hunt, C. D.; Herbel, J. L. \& Idso, J. P. Dietary boron modifies the effects of vitamin D3 nutrition on indices of energy substrate utilization and mineral metabolism in the chick. J. Bone Miner. Res., 9(2):171-81, 1994.

Hunt, C. D.; Shuler, T. \& Mullen, L. Concentration of boron and other elements in human foods and personal-care products. $J$. Am. Diet. Assoc., 91(5):558-68, 1991.

Irschik, H.; Schummer, D.; Gerth, K.; Höfle, G. \& Reichenbach, $\mathrm{H}$. The tartrolons, new boron-containing antibiotics from a myxobacterium, Sorangium cellulosum. J. Antibiot. (Tokyo), 48(1):26-30, 1995.

Kabu, M.; Birdane, F. M.; Civelek, T. \& Uyarlar, C. Affects of boron administration on serum $\mathrm{Ca}, \mathrm{Mg}$ and $\mathrm{P}$ for peripartum cows. Arch. Tierz., 56:733-41, 2013.

Ku, W. W. \& Chapin, R. E. Mechanism of the testicular toxicity of boric acid in rats: in vivo and in vitro studies. Environ. Health Perspect., 102(7):99-105, 1994.

Lovatt, C. J. \& Dugger, W. M. Boron. In: Frieden, E. (Ed.). Biochemistry of the essential trace elements. New York, Plenum Press, 1984.

Naghii, M. R. The significance of dietary boron, with particular reference to athletes. Nutr. Health, 13(1):31-7, 1999.

Newnham, R. E. Mineral imbalance and boron deficiency. In: Underwood, E. J. (Ed.). Trace elements in human and animal nutrition. 4th ed. New York, Academic Press, 1977.

Nielsen, F. H. Boron in human and animal nutrition. Plant Soil, 193(1-2):199-208, 1997.

Sabuncuoglu, B. T.; Kocaturk, P. A.; Yaman, O.; Kavas, G. O. \& Tekelioglu, M. Effects of subacute boric acid administration on rat kidney tissue. Clin. Toxicol. (Phila.), 44(3):249-53, 2006.

Weir, R. J. Jr. \& Fisher, R. S. Toxicologic studies on borax and boric acid. Toxicol. Appl. Pharmacol., 23(3):351-64, 1972.

Zafar, H. \& Ali, S. Boron inhibits the proliferating cell nuclear antigen index, molybdenum containing proteins and ameliorates oxidative stress in hepatocellular carcinoma. Arch. Biochem. Biophys., 529(2):66-74, 2013.

Correspondence to:

Assoc. Prof. Dr. Murat Tosun, MD PhD

Department of Histology and Embryology

Faculty of Medicine

Campus of Ali Cetinkaya

University of Afyon Kocatepe

Afyonkarahisar

TURKEY

Email: drmtosun@yahoo.com

Received: 16-06-2014

Accepted: 14-01-2015 